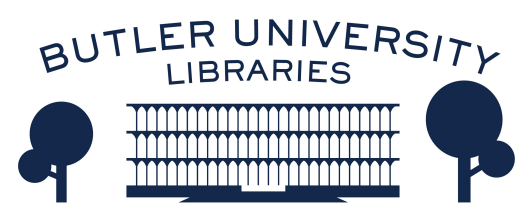

Journal of Hindu-Christian Studies

Volume 24

Article 5

November 2011

\title{
Playing in the Flood of Love: A Response to Michelle Voss Roberts' "Dualities: A Theology of Difference"
}

Brad Bannon

Follow this and additional works at: https://digitalcommons.butler.edu/jhcs

Part of the Religion Commons

\section{Recommended Citation}

Bannon, Brad (2011) "Playing in the Flood of Love: A Response to Michelle Voss Roberts' "Dualities: A Theology of Difference"," Journal of Hindu-Christian Studies: Vol. 24, Article 5.

Available at: https://doi.org/10.7825/2164-6279.1482

The Journal of Hindu-Christian Studies is a publication of the Society for Hindu-Christian Studies. The digital version is made available by Digital Commons @ Butler University. For questions about the Journal or the Society, please contact cbauman@butler.edu. For more information about Digital Commons @ Butler University, please contact digitalscholarship@butler.edu. 


\title{
Playing in the Flood of Love:
}

\section{A Response to Michelle Voss Roberts' Dualities: A Theology of Difference}

\author{
Brad Bannon \\ Harvard Divinity School
}

\begin{abstract}
AS John Thatamanil confesses in his Foreword to Michelle Voss Roberts' Dualities, I too, as a nondualist theologian, was initially apprehensive about Voss Roberts' title. However, I quickly came to find that the plural emphasis of dualities and the privative emphasis of non-dualism actually speak to similar concerns over the inadequacies of both monism and dualism. The dualism denied by non-dualism and the multiplicity and relationality affirmed by dualities are more harmonious than dissonant.

Dualities is not a work of detached metaphysics or historical comparison, though it certainly includes these. Rather, it is a creation of fruitful constructive and comparative theology. Employing an innovative methodology, Voss Roberts reanimates the voices of two women from the margins, Mechthild of Magdeburg and Lalleśvarī, exploring provocative metaphors of body, fluidity, and bodily fluids. In this response to her work, I first highlight compelling aspects of her methodology and then offer two constructive comparative theological metaphors of my own, inspired by and building upon her work. The final section is somewhat of a postscript, composed after our AAR panel discussion in November 2010. It looks towards a theology of play while responding to Voss Roberts'
\end{abstract}

concerns of theodicy in relation to ludic theology.

\section{Methodology}

There cannot be any clear demarcation between method and content; the "how" of our research greatly influences the "what" of our research. Michelle Voss Roberts' Dualities presents us with a new methodological approach which is more than simple variation or modulation of what has come before. This new method of comparison offers a unique fusion of constructive and comparative theology.

First, from the most pragmatic perspective, Dualities is quite readable and useful. Eschewing jargon and pedantic exposition, she elucidates Lalleśvarî's Kashmir Saivism and Mechthild's German beguine theology in a style sure to be interesting to scholars while remaining accessible to students of various levels. Furthermore, while the chapters fit well together in a discernable structure, each could also stand on its own, making the text all the more useful from a classroom perspective.

Second, Voss Roberts maintains balance between Lalleśvarī and Mechthild. Both are discussed and compared in each chapter. As a result, the reader is able to understand the

Brad Bannon is a doctoral student at Harvard Divinity School. His dissertation explores the significance of particularity and materiality in the apophatic theologies of Nicholas of Cusa and Śankara. His area of general interest is Hindu-Christian comparative theology, with a focus on epistemology, apophatic theology, and theology of the body. He has published The Quest for Postmodern Ethics: A Phenomenological Comparison of the Philosophies of Martin Heidegger and Sri Aurobindo Ghose (Dharmaram: 2007). Bannon is a member of the editorial board of several academic journals. He is also a candidate for ordination in the United Church of Christ. 
trajectory at every stage of the process. One never wonders "where are we going with this?" Through this method, we begin to read one author into the other even before the explicitly comparative portions.

There are, of course, benefits and detriments to this method. We sometimes risk losing sight of Mechthild and Lalleśvarī for the sake of seeing them both together. This is a notable contrast to Frank Clooney's methodology, which takes us deep into one tradition before any hint of comparison. By delving deeply into one thinker and tradition, our thinking processes, our presuppositions, and our reading strategies change. We do not simply come to know what the other is saying, but we begin, however tentatively and superficially, to conform to the other. As a result of this changed comportment, we then engage a text from our own tradition qua other, at least to a certain extent.

Even as these two methods sharply differ from one another (and there are many other variations, too), I mention the difference only to mark it and to enable us to add one more method to our toolbox. While it is important to be aware of the (potential) deficiencies of Voss Roberts' method, it is equally clear that this method bears its own fruit, as I explore in the next section.

Third, when we bend our ear towards voices from the past, it is important (and often frustrating) to remind ourselves that their questions are not necessarily our questions. In so doing, we might also imagine their frustration, were they with us today, that their questions are not ours. Thus, we should open ourselves to receive their questions even as we ask for their help with our own. Michelle Voss Roberts has done this, often explicitly, on both accounts. She writes, "Our two-way conversation will question certain aspects of premodern worldviews, just as the premoderns will certainly have something to teach us today" (84). For example, while global warming is a new problem, Voss Roberts demonstrates that Lalleśvarī and Mechthild offer important theological insights that can speak to contemporary ecological crises. Gender inequality and sexual marginalization, on the other hand, are hardly new problems and there can be no doubt that Lalleśvarī and Mechthild have much to say to us. Here, two specific points bear mention.

First, it is crucial that we attempt to understand, as best as we are able, how the weltanschauung of the other differs from our own. This is part-and-parcel of a hermeneutics of suspicion that enables us to contextualize statements made by our interlocutors. As an important example of this, Voss Roberts explains: "One of the fundamental differences between Mechthild's presuppositions and our own is that, unlike her, many contemporary readers assume that the social structures causing poverty can be changed" (137). Thus, only in light of such difference can we properly contextualize Mechthild's theodicy.

Second, Voss Roberts demonstrates that we can employ a hermeneutic of suspicion as a hermeneutic of retrieval, as Ricœur intended. Thus, we ask not simply: what does Lalleśvarī say about diversity and nature? Rather, we also ask why and when does she say what she says? For example, in chapter four, Voss Roberts draws our attention to passages by Mechthild and Lalleśvarī that seek transcendence and escape from the prison of the body. But she warns that "it would be a mistake to read this moment as the final act... [rather, it is] but one moment in the two women's processes of spiritual discernment" (91). Thus, we encounter stages of thought: one stage to realize oneness and a subsequent stage (jīvanmukta). Voss Roberts concludes, "Transcendence and the union of the void merely precede a return to the diversity of the world" (34).

Here we might pause to note that these voices from the margins offer us a different trope from the exitus-reditus pattern of much medieval Christian scholasticism. Dualities explores the worldviews of two women before and after divine union. The view of plurality as a fallen, fragmented lower state of the One gives way, after divine realization, to a celebratory view of dualities and multiplicity as divine manifestation. The reditus here is an exitus that does not exit. It is, once again, "a return to the diversity of the world" (34). We come to find that this diversity is infused with the flow of divinity. 
We should take particular notice of the method at work in this example. Voss Roberts' hermeneutics of suspicion qua retrieval can and should also be applied to other Indian theologians. In this way, Dualities provides us with a hermeneutical model by which we might read other authors. As a student of Śamkara, I am confronted with an overwhelming number of secondary treatments of his thought. Relatively few, however, have employed these hermeneutic strategies to his writing. Thus, I am grateful for Voss Roberts' work because it not only helps us to better understand Mechthild and Lalleśvarī, but also provides us with useful methods for hearing other voices of the past.

It is quite common for Western thinkers to be treated as dynamic thinkers. For example, we might discuss Wittgenstein's shift after Tractatus or Heidegger's kehre after Sein und Zeit, but we too often assume a stasis in the thought of pre-modern Indian theologians. Voss Roberts shows that, if we are careful, we might step back from a text and see how certain passages function in light of the whole.

\section{Two constructive theological metaphors}

Voss Roberts' work, as discussed above, presents us with a new method. Her fusion of constructive theology and comparative theology represents a valuable contribution to each field. She is not the first to have done so, as John Thatamanil rightly reminds me, but she does advance the method in fruitful ways. The voice of the "God of our Fathers" reverberates (even deafeningly) throughout the Bible and church history. The voice of the "God of our Mothers," however, is harder to hear and too easily muffled at the margins. One importance of a work like Dualities is that it retrieves these voices. But, even more, she engages them in a true dialogical retrieval through which the voices of Lalleśvarī, Mechthild, Voss Roberts, and the reader all participate.

Such a retrieval asks, who is the God of our mothers?-for these voices have been marginalized. But Voss Roberts goes further by exploring the ways in which these women engaged their own social milieu, ways that their theologies compelled them to challenge the status quo, and ways that it did not. The question of retrieval (who is the God of our mothers?) then becomes a question of construction: who may be the God of our daughters?

The result is an ethical motivation to alter the world in which we live, to increase the flow of divinity, and to open new channels/canals for participating in the playful flood of love. Or, in the prophetic words of Amos, the reader is invited to "let justice roll down like waters, and righteousness like an ever-flowing stream" $(5: 24)$.

\section{The Tide}

In that vein, I want to contribute two metaphors, thoroughly embodied and ubiquitous, in response Dualities. First, as valuable as the metaphor of flow and fluidity proves to be in Voss Roberts' work, it seems that most flows are one-directional. ${ }^{1}$ Rivers flow to the sea. Perhaps, though, we might envision this flow more in the sense of a tide that rises and falls - a flowing back and forth-a mutual permeability. I must hasten to add that tidal metaphors abound in Dualities and my contribution is more of an improvised riff than an original composition.

This perhaps resonates with Catherine Keller and process thought, but also with Śiva's perceiving-into-being, a doctrine dear to Lalleśvarī. Inasmuch as being is true being, truly free-to-be and possessed of true difference among persons, then Siva not only perceivesinto-being, but also sees what comes into and out of being. It is up to us whether or not this vision inspires weeping. Here, I am reminded of Luke 19:41: dominus flevit, the lord wept. The Latin word flevit derives from the Greek root flúo - to bubble-up, to overflow. Thus, there is an ethical dimension to this tidal God-flow that preserves freedom, avoids theodicy, and involves God both in our joy and sorrow, our pain and pleasure, our hope and despair.

Such a tidal flow raises daring questions: Why does Śiva open his eyes? Why does Śiva close his eyes? Does the flood of this kāla inevitably flow downstream towards degradation and despair that can only result in the bloodsoaked field of the kuruksetram? Or, might the 
tides be turned towards a kingdom of God or Rāmrājya that is not only always already yet-tocome as a messianic utopia, but also as a hereand-now eschatological field of becoming where we might sing and dance, rejoicing in the fact that God-Siva sees us and bubbles over (flúō) in an effervescent flow of joy, rather than with tears of despair (flēo).

The tide is a risky metaphor. There is a danger of being swept out to sea, in the chaotic depths where all is tohu va bohu. However, Lalleśvarî’s reanimated voice echoed by Voss Roberts informs us that it is our attachment to material things that causes us to drown. If we can simply let go, we might drift in the currents, swim in the waves, and dive into the abyss unfettered by our material anchors. "Only by letting go can we enjoy the ocean of this world without drowning," writes Voss Roberts (79). Lalleśvarī sings:

In the midst of being lost, I lost the sense of being lost[.]

After being lost I found myself in this worldly ocean[.]

Laughing and playing, I attained the allpervading Self[.] (106)

This tidal metaphor, given the size of the ocean, bears potential for infinity, and an infinity of potential, to borrow an image from Nicholas of Cusa. ${ }^{2}$ There is the possibility of renewing ourselves, reinvigorated by the inflow of the tide that also washes away our sorrows and releases them into the baptismal depths. Washed, the tide lifts us, lured upward by the moon perched upon Śiva's brow.

\section{Lìlā}

Lalleśvarī's poetic words bring us to the final metaphor I wish to propose. There is a thread woven through the pages of Voss Roberts' book. This is a thread that she does not explore in detail in Dualities, but one that I hope she will explore in the future. A theme that arises again and again in the words of both Lalleśvarī and Mechthild is, simply: play.

Humans play a role in global warming; Lalleśvarī laughs and plays in the worldly ocean
(106); my daughter plays with Legos; Mechthild's "soul plays with the Trinity 'a game that the body does not know" (90); Wisdom/Sophia "plays" (meśaheqet) with God and with creation in Proverbs 8:30-31. I submit that there are profound depths in the interplay of these uses/meanings of "play" in need of exploration and that this can best be done in and through comparative theology. Michelle Voss Roberts' work lays important groundwork here for development.

When my daughter, Leela, plays with Legos, she creates on several levels. She is literally creating: putting the pieces together in new ways. She reorders, or even transfigures, the blocks to create some new structure that may or may not "work." But she is also creating creativity both in a psychological-developmental sense, and also in an ontological sense. Creations of the mind struggle to find a place (to take place, Derrida would say). ${ }^{3}$ This is creativity literally playing out or playing-forth into being (as Heidegger has said). ${ }^{4}$

I was struck and moved by Mechthild's description of the Trinity as a "threefold playful flood" (38-40), an overflow of play. Like ocean tides, play ebbs and flows in a hermeneutical circle of playful fluidity. The placement of this Lego atop that one at once closes doors and opens new ones. Creativity is created and destroyed by the playing-forth of creativity itself. The wonderful thing about Legos is that they can be easily deconstructed. However, this is not the case for my small two year old daughter who is quick to say 'I'll do it! I'll do it!" when constructing but calls out "Help daddy! Help daddy!" when attempting to deconstruct. This piece does not belong here, but I need your help to pull them apart. Dualities and non-dualism, indeed.

Hegemony is easier to construct than to deconstruct. The pieces stick together, sometimes fusing to one another. For this, we need one another's help both to pullapart/deconstruct and also to identify/uncover oppressive structures. It is in this hermeneutical circle of uncovering (a-lêtheia) that we most need God and God's playing-forth into creativity. It is here in this threefold playful flood of mutual creativity that we can find the 
God that Heidegger sought: A God before whom we can sing and dance, ${ }^{5}$ like David's naked perichoresis (2 Samuel 6:5, 21), Kṛ̣ṇa's rāsa-līlā with the gopis, or Lalleśvarī's naked dance following her realization of the Self (120).

Voss Roberts shows us that "Mechthild's watery divinity promises that the soul 'shall ever more in soul and body soar about and play to her heart's content in [the] Holy Trinity..." (130131). Lalleśvarī muses: "However many roles I played on the stage of life... I am the same Lalla" (124). Further, Voss Roberts writes: "Mutuality, equality, and generativity mark these [Trinitarian] relations; and in the overflow of love, others are invited to play in the tide."

\section{Ludic Theology and Evils of the Game}

Like the other articles in this issue, an earlier version of the current essay was originally offered in Atlanta in November 2010 as part of an AAR panel on Dualities. In her response to our reflections on Dualities, Michelle Voss Roberts raised concerns about my ludic theological metaphor in relation to evil and suffering. Time restraints precluded a proper response at that time, so I offer one here. The problem of evil with respect to ludic theology is of utmost importance and seems, prima facie, to undermine a theology of play. However, it is a question that merits examination through the theologies of Mechthild and Lalleśvarī who make use of this notion in various ways. Unfortunately, I cannot answer based upon these thinkers, though I would be eager to read a close treatment of the topic by someone like Voss Roberts. Instead, I respond here from my own, still too inchoate, perspective which is considerably influenced by Nicholas of Cusa and others.

It seems to me that the issue of theodicy in ludic theology hinges upon our notions of freedom and power in relation to what is understood by play and the game. Are we 'playing a game' constructed by God? If so, then Voss Roberts' critique is well warranted, since such a game would lead us to theodicy and perverse explanations of suffering as part and parcel of God's game. From such a perspective, humans would be akin to pawns in God's game of life. Still worse, some would (arbitrarily?) play providential roles of kings, queens, bishops, and knights, etc.

A second perspective, though, would regard humans, nature, and God as equal players in this game of life shaped and constructed by humans. Inasmuch as the 'rules' of this game lead to suffering and oppression, then it is we, as free creators of these 'rules', who are responsible for suffering and oppression. This perspective, though, grants little power and responsibility to God. It is, more or less, the reverse of the theodicy problem. All suffering in the game of life is caused by the human rule-makers and God is a mere player who empathizes with sufferers.

What I propose is a third alternative in which God, humans, and nature are regarded as partners in the creation of this game of life that we play. God helps us to shape the rules of the game to the extent that we listen to and open ourselves to God. We distort the game of life (in this allegory which is only intended allegorically) when we distort the equal participation in rulemaking. That is, we distort the rule-making process when we do not listen to God, when we do not listen to nature, or when we do not listen to one another. The subaltern, as Gayatri Spivak asserts, has no voice. The subaltern is subaltern because he/she has been wrongly denied his/her voice in the rule-making process of this game of life.

From this vantage (still speaking allegorically, of course), we can appreciate a new value to Voss Roberts' work, which allows us to hear voices from the margins, such as those of Mechthild and Lalleśvarī. Furthermore, the praxis of Comparative Theology itself receives added value and significance. From one perspective, Śamkara's is anything but a marginal voice. His is a dominant voice ringing through centuries of Hindu orthodoxy and decades of Western academia. From another perspective, though, Śamkara's is undoubtedly a marginal voice in the history of Christian theology, Christian society, and American hegemonic hierarchy, simply by virtue of the fact that he falls outside of the Christian cumulative tradition. Likewise, we might say something similar about Nicholas of Cusa. From one vantage, his is a dominant voice: the voice 
of a Cardinal who was literally a rule-making canon lawyer who actively 'reformed' marginal communities in fifteenth century Germany, including the beguine communities of which Mechthild was a part. From another vantage, though, his is a marginal voice, heard by few and starkly unorthodox both in his time and in our own.

Hence, the allegory of the game of life and our playing of it-a playing with others, a playing with God, a playing with nature-can become a powerful and fruitful allegory when it confronts questions of theodicy, suffering, and oppression. It is not only 'how' and 'with whom' we play the game that matters, but also 'how' and 'with whom' we construct the game.

From this vantage, we can hear Mechthild's Trinitarian description of a threefold playful flood of love afresh. It is a threefold playful flood in which all voices (all rule-makers) matter. This threefold can map to the playful inter-creativity of human-nature-God. We play a theanthropocosmic game, Panikkar might say. Is this game in which all voices (human, nonhuman, and divine) participate in the rulemaking an impossible ideal? Indeed. It is, though, an impossible ideal that can be regulative; an ideal that encourages us to hear voices from the margins, to hear others into speech $^{6}$, to hear the subaltern who can have a voice if only we lend our ear. It is this game of life that we create, for good or for ill.

\section{Conclusion}

Michelle Voss Roberts's Dualities is
intellectually compelling, pedagogically
pragmatic, and methodologically innovative.
Even more, Voss Roberts reanimates the voice
of the "God of our Mothers," too long
marginalized, and helps us to give voice to the
"God of our daughters." Through a constructive
and comparative engagement with the writings
of Mechthild of Magdeburg and Lalleśvarī, she
demonstrates that the list of great thinkers of the
past is not limited to the narrow canon of pale
males dominating our history books. If we listen
to those voices from the margins, and if we truly
hear what they have to say, then we glean
wisdom to confront new problems like global

ecological degradation, and also find porous pathways for deconstructing marginalization itself. Relinquishing our attachment to materiality, to hegemonic hierarchy, and to transcendental authority, we might indeed "enjoy the ocean of this world without drowning," (79) ebbing and flowing together in that threefold playful flood of love of creation and restoration (38-40). These fluid, embodied, and ubiquitous metaphors promise to enrich our contemporary theologies, avoid the pitfalls of both monism and dualism, and demonstrate the fecund fusion of comparative and constructive theology. The theological allegories of tide and play explored too tenuously in this response represent, I hope, examples of how the voices of Mechthild, Lalleśvarī, and Voss Roberts inspire as they are received.

\section{Notes}

${ }^{1}$ In her AAR response to this essay, Voss Roberts emphasized that, for Mechthild, divinity always flows downward to the oppressed. This sentiment is certainly present in Amos 5:24, echoed above. Without denying or decrying this liberative metaphor, I seek simply to explore another.

2 In particular, see Cusano's De docta ignorantia on God as infinity and De apice theoria on God as Posse ipsum, though each idea is to be found throughout Cusano's work.

${ }^{3}$ See, for one example, Derrida's Sauf le nom and the relationships between creation, creativity, khora, and taking place

${ }^{4}$ See Heidegger's Beiträge zur Philosophie (Vom Ereignis), especially the second joining, "PlayingForth."

${ }^{5}$ Heidegger, Identity and Difference.

${ }^{6}$ Nelle Morton, Journey is Home. 